看護研究報告：

\title{
取手協同病院における感染対策委員会活動 新マニュアルによる職員教育
}

\author{
佐藤弘子*,菊地幸代 ${ }^{*}$, 久保田妙子*
}

当院における従来の感染対策マニュアルの活用状況を調査, 分析することで, 感染対策 新マニュアルの作成を行った。光れをもとに職員勉強会を実施, 感染対策への職員の意識 づけを目的とした。

感染防止対策は医療の急速な発展, 高度化に伴い, 日々変化している。当院では早期よ り感染対策マニュアルを作成, 修正が行われてきたが, 活用されない現状があった。关こ で, 従来のマニュアルの活用状況をアンケート調査 $(n=447) し$, マニュアルが活用さ れない原因を分析した。従来のマニュアルは, 古い, 分厚い, 読みづらいと不評であった が44 .7\%の人が活用していた。5 3\%の活用していない人は, 見てもわからない, 必要時 上司，同僚に聞くと答えている。これらの分析結果をふまえ，約 6 か月間を費やし，理解 しやすく，活用しやすい新マニュアルを作成した。職員全員に 1 冊ずつ手渡し，新マニュ アルをもとに職員勉強会を実施した。新マニュアルの紹介, 院内感染の定義, ユニバーサ ルプレコーションについて, 手洗いの仕方, 手袋 , マスクのつけ方の実技を行い知識の確 認を行った。パネルディスカッション形式で行われた勉強会は出席者が多く，感染対策へ の関心の高さを感じた。この勉強会を行ったことで職員の感染対策に対する意識を高める ことができた。また, 新マニュアルを学ぶことにより全てのスタッフに院内感染防止の重 要性を理解してもらうよい機会となった。

(1)感染対策 （2)新マニュアル（3)職員啓発

$$
\text { I . は じめに }
$$

当院における院内感染防止対策は早期から実 施されている。平成元年より感染対策委員会が 設置され, 感染対策マニュアルを作成し, 患者 や職員への感染を最小限にするよう努力してき た。近年の急速な医療の発展に伴い, 感染防止 対策もめまぐるしく変化している゙1ため, マ ニュアルの修正も炎の都度必要となる。しか し, マニュアルはあるが, 感染症発症時の対処 法か理解しづらい, など活用されない現状があ

* $=$ 302-0022 茨城県取手市本郷2-1-1

総合病院取手協同病院看護部

(受付 : 2003年 5 月14日)
る。乥こで今回，従来のマニュアルの活用状況 のアンケート調査を実施，分析した。产の結果 をもとに，理解しやすく，手軽に活用できる新 マニュアルを作成し, 職員勉強会を実施するこ とにより，職員の感染対策への意識も高まった ので報告する。

$$
\text { II. 方法 }
$$

1. 従来のマニュアルの活用状況調査

平成13年 7 月，従来の感染対策マニュアルの 活用状況を把握するため，医局，看護部，薬剂 部，放射線部，検査部など全職種を対象にアン ケート調査を行った。アンケート用紙は感染対 策チーム委員 (リンクナース) の協力により， 
配布，回収した。有効回答は447名から得られ た。

2 . 新マニュアルの作成

従来のマニュアルの活用状況のアンケート調 査結果の分析を行い, 従来のマニュアルが活用 されない理由を整理した。更に，アンケートの 中に数多くの貴重な意見か聞かれた。光れらを ふまえ, 新マニュアルの中心とする軸を 7 項目 に絞った。平成13年10月から平成14年 4 月まで の約 6 か月間, 臨時の委員会を数回開き，検討 を重ねながらマニュアルづくりをした。

\section{3 . 職員勉強会の開催}

新マニュアルをもとに職員勉強会を実施, 職 員の啓発をはかった。勉強会はパネルディス カッション形式で行い, 感染対策委員が各々の 演題を発表し, 兴の後, 活発な意見の交換が行 われた。勉強会は 4 月，7月，11月に実施し， 職員の感染対策への意識づけと院内で行ってい る感染防止対策についての再認識を行った。

III. 当院における感染対策委員会の構成

\section{1 . 院内感染対策の目的}

(1)感染発生の予防，防止

(2)感染発生時の疫学調査, 拡散防止対策の実 施と治療に対する助言

(3)再発防止

\section{2. 構成メンバー 表 1 参照}

3 . 活動状況表 2 参照

$$
\text { IV. 結果 }
$$

1 . 従来のマニュアル活用度のアンケート調査 結果

1 ) 人数の比率

全職種を対象とした結果，447名の有効回答 が得られた。看護職は患者と接する機会が多 く，感染防止の必要性が高いことからか，90\% 以上の人がアンケートに答えている。他の部は ほぼ同じ比率だった (図 1 )。

\section{2 ) マニュアル活用度}

活用している44 .7\%，活用していない55 3\% であり, 活用している人は半数以下であった (図 2 )。
3 ) マニュアル活用頻度

時折活用する $88.5 \%$, 月に 1 ～回活用する $8 \%$, 週に1〜2 回活用する2 $5 \%$, 毎日活用 する $1 \%$ \%゙った。マニュアルは活用されている が頻度は低かった (図 3 )。

4 ) マニュアルを活用していない理由 必要時上司，同僚に聞く36 8\%，見ても分か らない31 2\%，存在を知らなかった $162 \%$,多 忙6 .9\%, 弚の他 (興味がない, 必要性を感じ

表 1

\section{構成メンバー}

委員長 (医師) 1 名

委 員 医師 2 名、副看護部長、師長 3 名 臨床検査部、薬斉部、栄養部、事務部、 臨床工学科より 1 名ずつ

表 2

\section{活動状況}

(1)月 1 回、定例委員会開催、必要時は随時臨時委 員会を設ける

(2)委員会のもと、看護部内に活動チームを設置、 感染防止対策の浸透をはかる

(3)月 1 回、病棟、外来、清潔度調査の実施 (4)MRSA 発症率、抗生剂使用状況調査 (5)針さし事故、ゼロ月間キャンペーン実施 (6)院内感染対策ニュース発行 (7)院内感染対策マニュアル作成

1 ）人数の比率

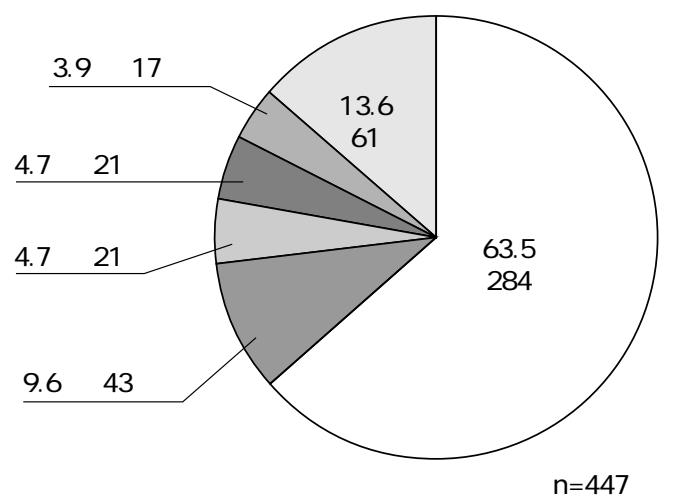

その他には栄養部, 事務部, ME, リハビリを含む 図 1 
2 ) マニュアルの活用度

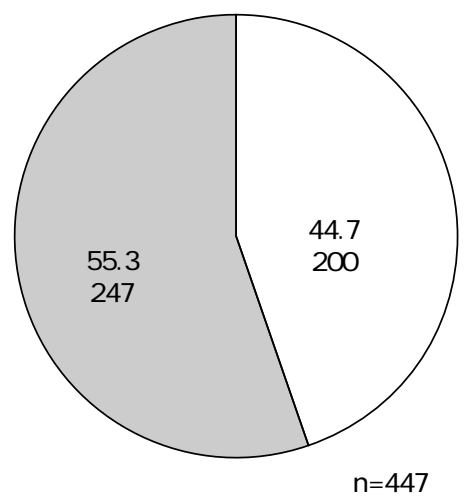

図 2

3 ) マニュアルを活用している頻度

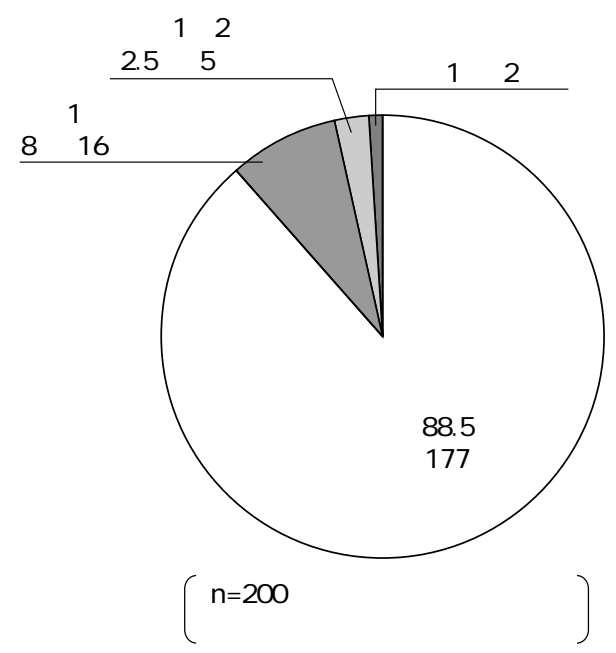

図 3

ない) 8 9\%だった。感染防止の必要性を感じ ながらも，解らない事は人に聞いてしまうとい う安易な方法が多くとられていることがわか る。また, 興味がない, マニュアルの必要性を 感じないと考えている一部の人の存在も浮上し た (図 4 )。

5 ) その他の意見として, 資料が古い, 分厚く 重い, 文章が多すぎる, 分類の仕方がわる い, 字が小さく見づらい, 大きくて移動が面 倒，感染対策の進歩についていっていない， 感染症発症時の対処法がわからない, などが あった。
4 ) マニュアルを活用していない理由 その他 $8.9 \%$ 22人)

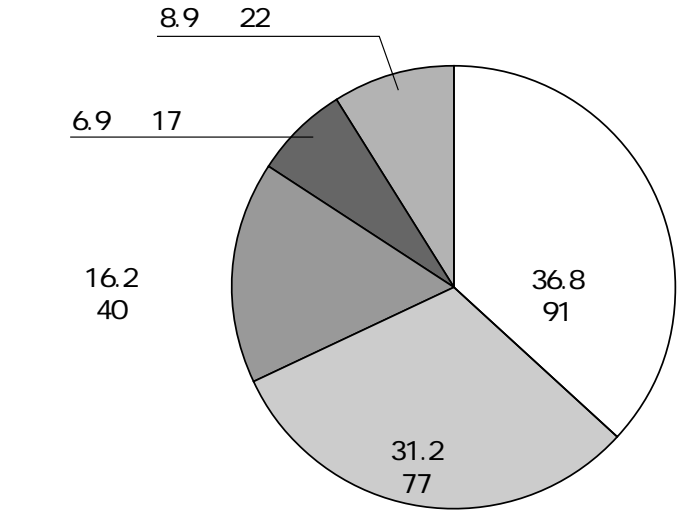

$\left(\begin{array}{l}\mathrm{n}=247 \text { 名 } \\ \text { マニュアルを活用していない人 }\end{array}\right)$

図 4

\section{2 . 新マニュアル作成}

従来のマニュアルの不評だった部分や活用さ れていない理由 (図 4 ) は従来のマニュアルが 臨床の現場に即していないためと思われた。従 来のマニュアルに対しての数多い意見の中から 検討すべき項目を抽出し，使いづらい部分，読 みにくい部分，余り役に立たない部分，に区分 けし改善策を検討した (表 3 )。炎の結果, 新 マニュアルは，(1)具体的，簡潔的にする，(2)文 章を少なく，表，イラストをとり入れる，(3)現 場に即したものとする，(4)枚数を減らし，手軽 に使えるようにする，(5)誰もが興味を持ち活用 できる，こととした。新マニュアルの 7 項目の 順番や文章の表現方法など前記の 5 条件に光っ て検討を重ね，マニュアル作成を行った。新マ ニュアル作成作業は，一つの項目を院内で統一 することの難しさに直面しながらも，感染対策 委員の意欲を高揚させ委員会の更なる団結と なった。新マニュアルは，約 6 か月の期間を要 したが，38頁の小冊子が完成し，職員全員に 1 冊ずつ配布した。これで新マニュアルを各自が 活用できるようになり，新マニュアルに光った 実践が可能になった。

3 . 職員勉強会 (表 4 ) 開催について

4 月，7月，11月に3 回続けて実施した職員 勉強会はパネルディスカッション形式で行われ 
表 3 . 従来マニュアルの検討すべき項目と改善策（アンケートより抜粋）

\begin{tabular}{|c|c|c|}
\hline 検討すべき項目 & & 改善策 \\
\hline ·分厚く重い & & ·枚数を少なくする \\
\hline · 大きくて面倒 & 使いづらい & ·持ちやすい大きさとする \\
\hline ·表現がわかりづらい & & ·具体的表現とする \\
\hline ·文章が多すぎる & & ·文章を少なく表をつくる \\
\hline • 字が小さここかすぎる & 読みにくい & ・絵を取り入れる \\
\hline · 区分け方が悪い & & ・項目ごとにまとめ調べやすくする \\
\hline •資料が古い & & •変化があった時は資料をさしかえる \\
\hline ·変化があるのについていってない & 余り役に立たない $\longrightarrow$ & ・最新版のマニュアルにつくりかえる \\
\hline •手もとにないのですぐ見れない & & ・1人1人に渡すとよい \\
\hline
\end{tabular}

表 4 . 職員勉強会の実施

\begin{tabular}{|c|c|c|}
\hline 第1 回パネルディスカッション & 第 2 回パネルディスカッション & 第 3 回パネルディスカッション \\
\hline $\begin{array}{l}\text { ·新マニュアル紹介 } \\
\text { · ユニバーサル・ブレコーション } \\
\text { について } \\
\text { ·手洗いについて } \\
\text { ·手袋マスクのつけ方 } \\
\text { (手洗い、手袋、マスクのつけ } \\
\text { 方の実技) } \\
\text { ·空気感染、飛沫感染、接触感染 } \\
\text { について } \\
\text { ·消毒薬について } \\
\text { ·抗生斉使用基準 }\end{array}$ & $\begin{array}{l}\text { ·手洗いと感染 } \\
\text { (手洗い前後のスタンプ検査) } \\
\cdot \text { · ME 機器と感染対策 } \\
\cdot \text { 院内巡視時の問題点 } \\
\text { ·抗菌薬届出制の提案 }\end{array}$ & $\begin{array}{l}\text { ·院内感染サーベイランスの実施 } \\
\text { にあたって } \\
\cdot \text { HIV 陽性患者の管理にあたっ } \\
\text { て } \\
\text { ·院内感染対策における細菌検査 } \\
\text { 室の役割と一年間の菌の検出状 } \\
\text { 況 } \\
\text { ・ ネブライザーポンプについて } \\
\text { 人工呼吸器の MRSA 感染統計 } \\
\text { から } \\
\text { • 回診車調査を実施して }\end{array}$ \\
\hline
\end{tabular}

た。院内で初めての試みのためか大勢の職員が 参加し , 積極的な意見の交換となった。

第1回目は新マニュアルの紹介，手洗いの仕 方, 感染経路別対応, 院内で使用されている消 毒剂について, などの演題が出された。手洗い の仕方は実技を行った。特殊蛍光阁による手洗

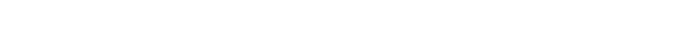
を行ったことで理論の再認識ができた。

第 2 回目の手洗い前後のスタンプ検査では， 第1 回目の手洗い実技の効果の検証を行った。 パームスタンプ検査法による手洗い前後の手指 培養検査は, 手指の杂隹菌の多さや手洗いの効果 か理解でき興味深いものだった。また, 院内巡 視時の問題点として, 新マニュアルに乥って病 室の環境整備や, 回診車の整理整頓などが行わ れ清潔が保たれているかを調査し “改善の必
要なところ”“工夫，改善されたところ”を写 真で紹介した。勉強会のあとの巡視では回診車 がきちんと整備されている，看護室は整理整頓 され廊下は不要なものは置いていないなど大き な変化があった。勉強会において写真で現状を 知らせることは視覚に訴えるため，非常に効果 的で良い結果をもたらした。

第 3 回目は感染対策委員会活動の報告や, 前 回の勉強会で問題点として残ったネブライ ザー, 吸引チューブについて検討された。ネブ ライザーの機械本体は定期的にME 室で清 掃・点検する。ネブライザーチューブは 1 週間 に1回交換し，オートクレーブ消毒をする。嘴 管は炎の都度0 .01\%次亜塩素酸 (ミルトン) で 消毒, 弚の後食器乾燥器で熱を加え乾かすこと とした。院内感染サーベイランスも積極的に行 
勉強会について

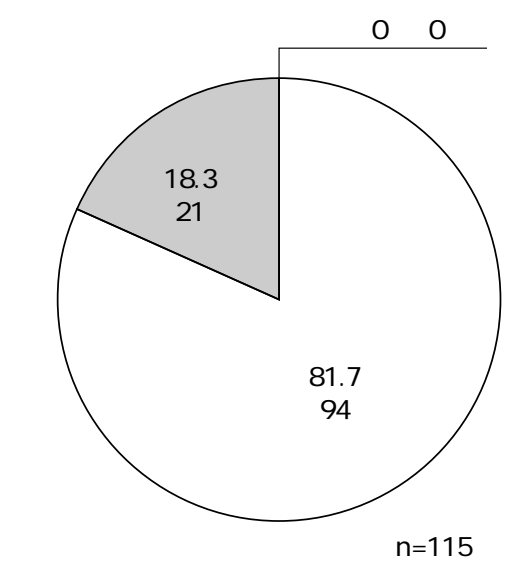

マニュアルについて

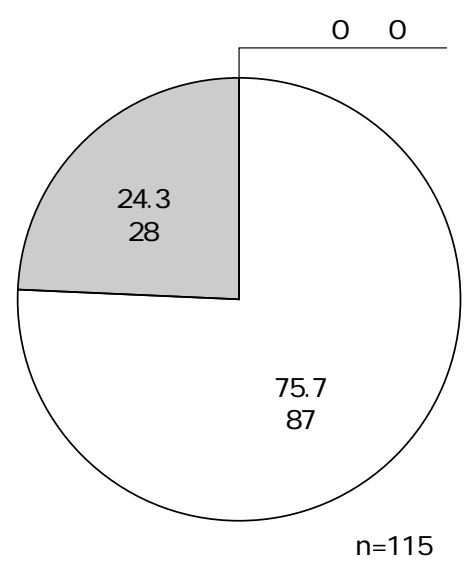

図 5

うこととした。

第1 回目の勉強会に参加した199名のうち115 名に意見を聞いたところ, 勉強会は, よかった 94名 (81.7\%)，ふつう21名 (18 3\%), 悪い0 名 $(0 \%)$, 新マニュアルはわかりやすい 87 名 (75.7\%)，ふつう28名 (24 3\%), 悪い0名 ( 0 \% ) だった (図 5 )。新マニュアルはイラ ストが入り見やすくなった，系統だてて分けて ある，いろいろな職種の人が見てもわかりやす い, 身近な内容が実践しやすく整理されてい る, などの意見が聞かれたが, カラー版にする ともっと興味が湧く，細かい手順を追加した方 がよい,と言う指摘もあった。また，パネル ディスカッションに対しては, 講義だけでなく 意見が聞かれてよかった，同じような㥗みを
持った人がいて安心した, 全職員が同じレベル で受講できた事は病院全体のレベルアップにな る，感染防止は病院全体の問題だということを 知った，など，感染対策に前向きな意見が多く 聞かれたが, 感染対策は理解したころにすぐ変 更になるので覚えきれない, との率直な意見も あった。

$$
\mathrm{V} \text {. 考察 }
$$

院内感染防止活動を効果的に行うには, 職員 の意識づけが最も重要と考える。

今回，続けて職員勉強会を開催することで全 体の職員に感染対策への意識づけを推進した。 従来, マニュアルはあっても業務に流され対応 ができなかったこと，感染対策が病院全体のこ とと受けとめられていなかったことを大きな反 省とし, 勉強会において新マニュアルの周知徹 底を計った。更に感染対策委員会, 及び, チー 么委員会委員が組織的活動をしたことで, 全体 の職員の感染対策への積極的姿勢をよび起こす ことができたと考える。職員の積極的姿勢は， 各部署から委員へ感染対策への問い合わせが多 くなったこと，各部署の目につく所に新マニュ アルが置かれるようになったこと，医療器材の 洗浄の仕方や持ち運び時に，以前より注意をは らうようになったこと，使用後の流し台が磨か れ乾燥されているようになったこと，手洗いや うがいがきちんとできるようになったこと，な どから読みとれた。

また, 毎月開催するチーム委員会では, 新マ ニュアルの読み合わせをし, 委員が新マニュア ルの内容を熟知するよう努力している。感染症 が発生したら新マニュアルを見ることを習慣づ ける，院内巡視は毎月実施し，新マニュアルに そった対応がされているか確認する, 各部署で 新マニュアルに光った実践を指導する，など， 委員の日々の地道な活動こ光, 職員の感染対策 の意識づけの原動力となっている。

感染予防を普及することで感染率は大幅に低 下する。二次的効果として医療費のコストの削 減につながっていると APIC のダッシュ氏は述 べている。感染防止対策は一部の人の努力では 
行えない, 病院全体でとり組むことが重要であ る2)。新マニュアルの配布, 勉強会の開催な ど，常に感染防止対策を意識づけておくための 啓発活動が大切と考える。問題発生時は現場に 出向き，現場の人と共にマニュアルを実践し， 解決策を練る゙〉。現場に出向くことは問題を抽 出しやすく，マニュアルの浸透を計りながら臨 床に即した対応がとれ，感染対策委員の積極的 姿勢をアピールでき，職員の意識づけになる。 また，医療の進歩に伴い日々変化していく感染 防止対策をいち早くキャッチし，わかりやすく 現場に反映させることも私達の大きな任務と考 える。しかし, 興味がない, 必要性を感じない という感染に対する関心の薄い職員への意識改 革の教育か課題として残った。

結論

院内感染が一度発生すると医療の質は低下す
る。患者は原疾患の他に感染症による身体的苦 痛, 精神的苦痛, 入院日数の延長, 経済的負担 を強いられる4)。

院内感染防止をより効果的に進めるために は，医師や看護師だけでなく全職員に感染防止 の重要性を理解してもらうことが重要である。 定期的な巡視, 新マニュアルの作成, パネル ディスカッションによる勉強会の実施などは， 感染対策の意識づけ，職員教育に有効であっ た。

$$
\text { 参 考 文 献 }
$$

1 ) ICHG 研究会監修.ユニバーサルプレコーション 実践マニュアル. 南江堂, 2001.

2 ) 関りゅう子 . 看護部における感染対策とリンクナー スの活動. 婦長主任新事情, No 81, P 22-28.

3 ) 隅田秀子. 手作りの感染防止対策. 感染と消毒 1999 ; Vol .6 No.2 : 42-43.

4 ) 日本感染症学会監修. 改訂 院内感染対策テキス 卜.ヘルス出版，2001. 


\title{
In-H ouse Education by Use of New Manual for Infections Disease Prevention in Our Hospital
}

\author{
Hiroko SATO* , Sachiyo KIKUCHI * and Taeko KUBOTA*
}

A new edition of infection control manual was brought out after months of reviewing the utility of the preceding edition. Using the new manual, a series of study meetings were held with the aim of raising awareness among the personnel of infection prevention.

Preventive measures have been changing with rapid advances in medical treatment. The old manual, which had undergone revision repeatedly, was not utilized fully.

In view of the situation, questionnaires were distributed to all the members of the hospital staff $(n=447)$ to investigate the reasons why the manual had not been utilized. Although many respondents were of the opinion that the old manual was out of date, too thick, and unreadable, $44.7 \%$ said they had used it. $55.3 \%$ answered that they had asked their superiors or colleagues out of necessity. Based on these results, we started making a compilation of a new manual, easy to understand and friendly to the users. It took about six months to complete it. Copies of the new manual were given to all the staff members. In the study meetings, various subjects were taken up for discussion, including the definition of nosocominal infection, "universal precaution," how to effectively wash your hands, how to keep the rest rooms clean, how to wear the gloves and mask, and so forth. We believe that the personnel's consciousness of infection prevention was further raised by holding the study meetings.

*Nursing Dept. TorideKyodo General Hospital , I baraki, J apan 